\title{
Correlation Studies of Yield and Yield Contributing Characters and Quality Parameters of Elephant Foot Yam (Amorphophallus Paeoniifolius Dennst.) Under The Influence of Different Organic and Inorganic Substances
}

\author{
Dr. Sarita Sahu ${ }^{1}$ and Dr. Vijay Kumar ${ }^{2}$ \\ Indira Gandhi Krishi Vishwavidyalaya, Raipur (C.G.) \\ ${ }^{1}$ Assistant Professor, RMD College of Agriculture \& Research Station, Ambikapur (C.G.) \\ ${ }^{2}$ Professor, Dept. of Horticulture, College of Agriculture, Raipur (C. G.)
}

\begin{abstract}
All the yield attributing characters were found to be positively correlated with each other which consequently improved the corm yield significantly over the two years (2010-11 and 2011-12). The corm yield had negative and significant correlation with days to 50 per cent emergence $(r=-0.934)$. However, it showed positive and significant correlations with plant height $(r=0.938)$, pseudo-stem girth $(r=0.966)$, number of pseudo-stem plant ${ }^{-1}(r=0.932)$, canopy spread $(r=0.964)$, days to maturity $(r=0.972)$, corm yield plant $t^{-1}(r=$ $0.969)$, corm diameter $(r=0.968)$, dry matter content of corm $(r=0.930)$ and starch content of corm $(r=$ $0.887)$.
\end{abstract}

Key words: Correlation, Elephant foot yam, yield, quality

\section{Introduction}

Elephant foot yam (Amorphophallus paeoniifolius Dennst.) is one of the important tuber crops widely cultivated in sub-tropical regions for its underground food reserves. It is gaining wide acceptability due to its better cooking quality, palatability and various uses in boiled or baked forms and pickles and flours. Even the stem and flowers are used as food (Raghu et al., 1999). In India, the elephant foot yam is commercially cultivated in Andhra Pradesh, Bihar, West Bengal, Orissa, Gujarat, Kerala and North-Eastern states (Nedunchezhiyan et al., 2006). Besides, other growing states are Maharashtra, Tamil Nadu, Jharkhand and Chhattisgarh. Gajendra variety of elephant foot yam is high yielding, free from acridity and is popularly grown all over India as well as Chhattisgarh. It requires huge quantity of seed material, non-availability of planting material and dormancy of tubers is a major constraint of this crop. Therefore, the present study was to examine the characters which associate to increase the yield of elephant foot yam.

\section{Materials And Methods}

The experiment was conducted at Research and Instructional Farm of Department of Horticulture, Indira Gandhi Krishi Vishwavidyalaya, Raipur, Chhattisgarh during Kharif season of the years 2010-11 and 2011-12.The experiments were laid out in Randomized Block Design (RBD) with fifteen treatments and three replications. The treatment consisted of different concentrations of organic and inorganic substances which were applied as pre-planting soaking of corms. Minisetts of weight $100 \mathrm{~g}$ were planted vertically in the month of July at spacing of $60 \times 60 \mathrm{~cm}$ in pits of size $30 \times 30 \times 30 \mathrm{~cm}$ at a depth of $10-15 \mathrm{~cm}$ after treating these minisetts with fungicide (Dithane M-45 @ $2.5 \mathrm{~g} \mathrm{~L}^{-1}$ ) followed by pre-planting soaking for one hour in different organic and inorganic substances as per treatments. The farm yard manure (FYM) was incorporated in the soil @ $200 \mathrm{q}$ ha ${ }^{-1}$ before planting of minisetts. Recommended dose of nitrogen, phosphorus and potassium were applied @ 100:60:100 $\mathrm{kgha}^{-1}$ in the form of urea, single super phosphate and murate of potash, respectively. The entire quantity of phosphorus and one third dose of nitrogen and potassium were incorporated as basal applications. However, rest of two, one-third doses of each nitrogen and potassium were applied in two equal splits at 60 and 90 days after planting (DAP).The crop was harvested in the month of February when leaves turn yellow and start drying. Ten plants were sampled randomly from the each plot for recording data on days to 50 per cent emergence, plant height $(\mathrm{cm})$, pseudo-stem girth $(\mathrm{cm})$, number of pseudo-stem plant ${ }^{-1}$, canopy spread $(\mathrm{cm})$, days to maturity, corm yield kg plant-1, corm yield (t ha-1) and diameter of corm $(\mathrm{cm})$, and quality parameters such as dry matter (\%) and starch content (\%). The first year (2010-11), second year (2011-12) and pooled data were analysed for correlation coefficient.

The correlation coefficient (r) between different characters and quality parameters was carried out according to Panse and Sukhatme (1985). 


$$
\mathrm{r}=\frac{\operatorname{covariance}(\mathrm{X}, \mathrm{Y})}{\sqrt{\operatorname{variance}(\mathrm{X}) \operatorname{variance}(\mathrm{Y})}}
$$

The test of significance of correlation coefficient was tested by using t- test value and show significant correlation if the calculated $t$-value is greater than the tabulated $t$-value at 5 per cent level of significance with $(n-2)$ degree of freedom.

\section{Results And Discussion}

The correlation coefficient of yield and yield contributing characters and quality parameters studied during both the years (2010-11 and 2011-12) and pooled data are presented in Table 1 to3 and Fig. 1 to 10. The correlation studies during first year (2010-11) indicated that the corm yield was negatively and significantly correlated with days to 50 per cent emergence $(r=-0.914)$. However, it showed positive and significant correlation with plant height $(r=0.961)$, pseudo-stem girth $(r=0.984)$, number of pseudo-stem plant ${ }^{-1}(r=$ $0.928)$, canopy spread $(r=0.977)$, days to maturity $(r=0.947)$. The corm yield plant ${ }^{-1}(r=0.965)$, diameter of corm $(r=0.964)$, dry matter content of corm $(r=0.930)$ and starch content of corm $(r=0.789)$ were also found to be positive correlation with this character. The study revealed that significant positive correlation between diameter and dry matter content of corm $(\mathrm{r}=0.963)$. The yield attributing characters like plant height $(\mathrm{r}=-$ $0.900)$, pseudo-stem girth $(r=-0.895)$, number of pseudo-stem plant $^{-1}(r=-0.878)$, canopy spread $(r=-0.907)$, days to maturity $(r=-0.953)$, diameter of corm $(r=-0.930)$, dry matter content of corm $(r=-0.828)$ and starch content of corm $(\mathrm{r}=-0.641)$ were found to be negatively and significantly correlated with days to 50 per cent emergence. Significant positive correlations were found between plant height and pseudo-stem girth $(\mathrm{r}=0.962)$, number of pseudo-stem plant ${ }^{-1}(r=0.930)$, canopy spread $(r=0.973)$, days to maturity $(r=0.901)$, diameter of corm $(r=0.978)$, dry matter content of corm $(r=973)$ and starch content of corm $(r=0.790)$.

During second year (2011-12), almost similar trend was noticed in relation to correlation studies. The corm yield had positive and significant correlations with plant height $(\mathrm{r}=0.868)$, pseudo-stem girth $(\mathrm{r}=0.913)$, number of pseudo-stem plant ${ }^{-1}(r=0.920)$, canopy spread $(r=0.925)$, days to maturity $(r=0.953)$, corm yield plant $^{-1}(\mathrm{r}=0.957)$, corm diameter $(\mathrm{r}=0.958)$, dry matter content of corm $(\mathrm{r}=0.918)$ and starch content of corm $(\mathrm{r}=0.752)$. However, days to 50 per cent emergence showed a negative and significant correlation $(r=-0.959)$ with these characters.

In case of pooled data, almost similar trend was noticed in relation to correlation studies. The corm yield had negative and significant correlation with days to 50 per cent emergence $(r=-0.934)$. However, it showed positive and significant correlations with plant height $(\mathrm{r}=0.938)$, pseudo-stem girth $(\mathrm{r}=0.966)$, number of pseudo-stem plant ${ }^{-1}(r=0.932)$, canopy spread $(r=0.964)$, days to maturity $(r=0.972)$, corm yield plant ${ }^{-1}(r=$ $0.969)$, corm diameter $(r=0.968)$, dry matter content of corm $(r=0.930)$ and starch content of corm $(r=0.887)$. In correlation studies, all the yield attributing characters and quality parameters were positively correlated with each other except the days to 50 per cent emergence which was negatively and significantly correlated with all the characters. Similar results were obtained by Kumar et al.(2010) who revealed that the corm yield of elephant foot yam had significant positive correlations with starch content, plant height, weight of individual corm, size of individual corm, stem girth, canopy spread and dry matter. Germchi et al. (2011) reported negative link between plant height and number of days until germination in potato and positive relationship between tuber numbers plant ${ }^{-1}$ with plant height. It seems that thiourea by increasing plant height, also increased stems number and declined emergence period and which led to increase in tuber weight (Rezaee and Soltani, 1996).

\section{Conclusion}

In correlation studies of yield and yield contributing characters and quality parameters of elephant foot yam, corm yield was negatively and significantly correlated with days to 50 per cent emergence. However, it showed positive and significant correlation with plant height, pseudo-stem girth, number of pseudo-stem plant ${ }^{-1}$, canopy spread, days to maturity, corm yield plant ${ }^{-1}$, diameter of corm, dry matter content of corm and starch content of corms.

\section{Acknowledgement}

I am grateful to Head, Department of Horticulture, College of Agriculture, Raipur and Director Research Services, Indira Gandhi Krishi Vishwavidyalaya, Raipur (C.G.) for proving necessary facilities and infrastructure for this study.

\section{References}

[1]. Germchi, Sardar, Behroozi, FarimahGhanna and Badri, Samira. 2011. International conference on environmental and agriculture engineering, IPCBEE vol. 15, IACSIT Press, Singapore. pp. 19-24.

[2]. Kumar, Santosh, Singh, P.K., Kumar, K. and Singh, B. K. 2010. Variability and Character Association in Elephant Foot Yam [Amorphophallus paeoniifolius (Dennst.) Nicolson]. J. Root Crops,36 (1): 105-110. 
[3]. Nedunchezhiyan, M., Saurabh, A. and Ranasingh, N. 2006. Elephant foot yam: A commercial crop for Orissa. Orissa Rev., 63 (1):71-72.

[4]. Panse, V.G. and Sukhatme, P.V. 1985. Statistical methods for Agricultural Workers. IV ed. Indian Council of Agricultural Research, New Delhi. p.381.

[5]. Raghu, A., Deepa, V.C. and Sundarn, K. 1999. A study on Soorana (Amorphophallus paeoniifolius) The king of tubers, In: Tropical Tuber crops in Food Security and Nutrition. Oxfort\& IBH Publishing Co. Pvt. Ltd., New Delhi. pp. 10-14.

[6]. Rezaee, A. and Soltani, A. 1986. Potato production. Mashhad University Publication, Iran.

Table 1: Correlation coefficient of yield, yield attributing characters and quality parameters of elephant foot yam cv. Gajendra (2010-11)

\begin{tabular}{|c|c|c|c|c|c|c|c|c|c|c|}
\hline & $\begin{array}{c}\text { Days to } \\
50 \% \\
\text { emergence }\end{array}$ & $\begin{array}{c}\text { Plant } \\
\text { height } \\
(\mathrm{cm})\end{array}$ & $\begin{array}{l}\text { Pseudo- } \\
\text { stem } \\
\text { girth } \\
(\mathrm{cm}) \\
\end{array}$ & $\begin{array}{l}\text { No. of } \\
\text { pseudo- } \\
\text { stem } \\
\text { plant }^{-1}\end{array}$ & $\begin{array}{l}\text { Canopy } \\
\text { spread } \\
(\mathrm{cm})\end{array}$ & $\begin{array}{l}\text { Days to } \\
\text { maturity }\end{array}$ & $\begin{array}{l}\text { Corm yield } \\
\left(\mathrm{kg}_{\text {plant }}{ }^{-1}\right)\end{array}$ & $\begin{array}{l}\text { Corm } \\
\text { yield } \\
\left(\mathrm{t} \mathrm{ha}^{-1}\right)\end{array}$ & $\begin{array}{l}\text { Diameter } \\
\text { of corm } \\
(\mathrm{cm})\end{array}$ & $\begin{array}{c}\text { Dry } \\
\text { matter of } \\
\text { corm }(\%)\end{array}$ \\
\hline $\begin{array}{l}\text { Plant height } \\
(\mathrm{cm})\end{array}$ & $-0.900^{* *}$ & & & & & & & & & \\
\hline $\begin{array}{l}\text { Pseudo-stem } \\
\text { girth }(\mathrm{cm})\end{array}$ & $-0.895^{* *}$ & $0.962^{* *}$ & & & & & & & & \\
\hline $\begin{array}{l}\text { No. of } \\
\text { pseudo-stem } \\
\text { plant }^{1}\end{array}$ & $-0.878^{* *}$ & $0.930^{* *}$ & $0.932^{* *}$ & & & & & & & \\
\hline $\begin{array}{l}\text { Canopy } \\
\text { spread }(\mathrm{cm})\end{array}$ & $-0.907^{* *}$ & $0.973^{* *}$ & $0.974^{* *}$ & $0.938^{* *}$ & & & & & & \\
\hline $\begin{array}{l}\text { Days to } \\
\text { maturity }\end{array}$ & $-0.953^{* *}$ & $0.901^{* *}$ & $0.911^{* *}$ & $0.886^{* *}$ & $0.945^{* *}$ & & & & & \\
\hline $\begin{array}{l}\text { Corm yield } \\
\left(\mathrm{kg} \text { plant } \mathrm{t}^{-1}\right)\end{array}$ & $-0.902^{* *}$ & $0.919 * *$ & $0.944^{* *}$ & $0.833^{* *}$ & $0.939 * *$ & $0.954^{* *}$ & & & & \\
\hline $\begin{array}{l}\text { Corm yield } \\
\left(t_{h a}^{-1}\right)\end{array}$ & $-0.914^{* *}$ & $0.961^{* *}$ & $0.984^{* *}$ & $0.928^{* *}$ & $0.977^{* *}$ & $0.949 * *$ & $0.965^{* *}$ & & & \\
\hline $\begin{array}{l}\text { Diameter of } \\
\text { corm }(\mathrm{cm})\end{array}$ & $-0.930^{* *}$ & $0.978^{* *}$ & $0.959 * *$ & $0.939^{* *}$ & $0.980^{* *}$ & $0.951^{* *}$ & $0.941^{* *}$ & $0.964^{* *}$ & & \\
\hline $\begin{array}{l}\text { Dry matter of } \\
\text { corm }(\%)\end{array}$ & $-0.828^{* *}$ & $0.973^{* *}$ & $0.938^{* *}$ & $0.916^{* *}$ & $0.959 * *$ & $0.855^{* 8}$ & $0.884^{* *}$ & $0.930^{* *}$ & $0.963^{* *}$ & \\
\hline Starch $(\%)$ & $-0.641^{* *}$ & $0.776^{* *}$ & $0.814^{* *}$ & $0.729 * *$ & $0.775^{* *}$ & $0.622^{* *}$ & $0.803^{* *}$ & $0.790^{* *}$ & $0.699 * *$ & $0.767^{* *}$ \\
\hline
\end{tabular}

Note: ** significant at $1 \%$ level

Table 2: Correlation coefficient of yield, yield attributing characters and quality parameters of elephant foot yamcv. Gajendra (2011-12)

\begin{tabular}{|c|c|c|c|c|c|c|c|c|c|c|}
\hline & $\begin{array}{c}\text { Days to } \\
50 \% \\
\text { emergence }\end{array}$ & $\begin{array}{l}\text { Plant } \\
\text { height } \\
(\mathrm{cm})\end{array}$ & $\begin{array}{l}\text { Pseudo- } \\
\text { stem } \\
\text { girth } \\
(\mathrm{cm}) \\
\end{array}$ & $\begin{array}{c}\text { No. of } \\
\text { pseudo-stem } \\
\text { plant }^{-1}\end{array}$ & $\begin{array}{l}\text { Canopy } \\
\text { spread } \\
(\mathrm{cm})\end{array}$ & $\begin{array}{l}\text { Days to } \\
\text { maturity }\end{array}$ & $\begin{array}{l}\text { Corm yield } \\
\left(\mathrm{kg} \mathrm{plant}^{-1}\right)\end{array}$ & $\begin{array}{l}\text { Corm } \\
\text { yield } \\
\left(\mathrm{t} \mathrm{ha}^{-1}\right)\end{array}$ & $\begin{array}{l}\text { Diameter } \\
\text { of corm } \\
(\mathrm{cm})\end{array}$ & $\begin{array}{c}\text { Dry } \\
\text { matter } \\
\text { of corm } \\
(\%)\end{array}$ \\
\hline $\begin{array}{l}\text { Plant height } \\
(\mathrm{cm})\end{array}$ & $-0.853^{* *}$ & & & & & & & & & \\
\hline $\begin{array}{l}\text { Pseudo-stem } \\
\text { girth }(\mathrm{cm})\end{array}$ & $-0.941^{* *}$ & $0.951^{* *}$ & & & & & & & & \\
\hline $\begin{array}{l}\text { No. of } \\
\text { pseudo-stem } \\
\text { plant }^{-1}\end{array}$ & $-0.934^{* *}$ & $0.857^{* *}$ & $0.944^{* *}$ & & & & & & & \\
\hline $\begin{array}{l}\text { Canopy } \\
\text { spread }(\mathrm{cm})\end{array}$ & $-0.929^{* *}$ & $0.964^{* *}$ & $0.972^{* *}$ & $0.949^{* *}$ & & & & & & \\
\hline $\begin{array}{l}\text { Days to } \\
\text { maturity }\end{array}$ & $-0.941^{* *}$ & $0.936^{* *}$ & $0.976^{* *}$ & $0.953^{* *}$ & $0.972^{* *}$ & & & & & \\
\hline $\begin{array}{l}\text { Corm yield } \\
\left(\mathrm{kg} \mathrm{plant}^{-1}\right)\end{array}$ & $-0.948^{* *}$ & $0.886^{* *}$ & $0.937^{* *}$ & $0.881^{* *}$ & $0.899 * *$ & $0.953^{* *}$ & & & & \\
\hline $\begin{array}{l}\text { Corm yield } \\
\left(t_{h a}^{-1}\right)\end{array}$ & $-0.959 * *$ & $0.868^{* *}$ & $0.913^{* *}$ & $0.920^{* *}$ & $0.925^{* *}$ & $0.953^{* *}$ & $0.957^{* *}$ & & & \\
\hline $\begin{array}{l}\text { Diameter of } \\
\operatorname{corm}(\mathrm{cm})\end{array}$ & $-0.967^{* *}$ & $0.914^{* *}$ & $0.958 * *$ & $0.935^{* *}$ & $0.951^{* *}$ & $0.951^{* *}$ & $0.944^{* *}$ & $0.958^{* *}$ & & \\
\hline $\begin{array}{l}\text { Dry matter of } \\
\operatorname{corm}(\%)\end{array}$ & $-0.894^{* *}$ & $0.948^{* *}$ & $0.948^{* *}$ & $0.938 * *$ & $0.967^{* *}$ & $0.943^{* *}$ & $0.885^{* *}$ & $0.918^{* *}$ & $0.959 * *$ & \\
\hline Starch $(\%)$ & $-0.829 * *$ & $0.768^{* *}$ & $0.819^{* *}$ & $0.684^{* *}$ & $0.737^{* *}$ & $0.754^{* *}$ & $0.894^{* *}$ & $0.752^{* *}$ & $0.818^{* *}$ & $0.725^{* *}$ \\
\hline
\end{tabular}

Note: $* *$ significant at $1 \%$ level 
Correlation Studies of Yield and Yield Contributing Characters and Quality Parameters of...

Table 3: Correlation coefficient of yield, yield contributing characters and quality parameters of elephant foot yam cv. Gajendra (pooled data)

\begin{tabular}{|c|c|c|c|c|c|c|c|c|c|c|}
\hline & $\begin{array}{c}\text { Days to } \\
50 \% \\
\text { emergence }\end{array}$ & $\begin{array}{l}\text { Plant } \\
\text { height } \\
(\mathrm{cm})\end{array}$ & $\begin{array}{l}\text { Pseudo- } \\
\text { stem girth } \\
(\mathrm{cm})\end{array}$ & $\begin{array}{l}\text { No. of } \\
\text { pseudo- } \\
\text { stem } \\
\text { plant }^{-1}\end{array}$ & $\begin{array}{l}\text { Canopy } \\
\text { spread } \\
(\mathrm{cm})\end{array}$ & $\begin{array}{l}\text { Days to } \\
\text { maturity }\end{array}$ & $\begin{array}{l}\text { Corm yield } \\
\left(\mathrm{kg} \mathrm{plant}^{-1}\right)\end{array}$ & $\begin{array}{l}\text { Corm } \\
\text { yield } \\
\left(\mathrm{t} \mathrm{ha}^{-1}\right)\end{array}$ & $\begin{array}{l}\text { Diameter } \\
\text { of corm } \\
(\mathrm{cm})\end{array}$ & $\begin{array}{c}\text { Dry } \\
\text { matter of } \\
\text { corm }(\%)\end{array}$ \\
\hline $\begin{array}{l}\text { Plant height } \\
(\mathrm{cm})\end{array}$ & $-0.911^{* *}$ & & & & & & & & & \\
\hline $\begin{array}{l}\text { Pseudo-stem } \\
\text { girth }(\mathrm{cm})\end{array}$ & $-0.953^{* *}$ & $0.973^{* *}$ & & & & & & & & \\
\hline $\begin{array}{l}\text { No. of } \\
\text { pseudo-stem } \\
\text { plant }^{1}\end{array}$ & $-0.917^{* *}$ & $0.907^{* *}$ & $0.950^{* *}$ & & & & & & & \\
\hline $\begin{array}{l}\text { Canopy } \\
\text { spread }(\mathrm{cm})\end{array}$ & $-0.946^{* *}$ & $0.983^{* *}$ & $0.986^{* *}$ & $0.954^{* *}$ & & & & & & \\
\hline $\begin{array}{l}\text { Days to } \\
\text { maturity }\end{array}$ & $-0.979 * *$ & $0.939 * *$ & $0.979 * *$ & $0.936^{* *}$ & $0.973^{* *}$ & & & & & \\
\hline $\begin{array}{l}\text { Corm yield } \\
\left(\mathrm{kg} \mathrm{plant}^{-1}\right)\end{array}$ & $-0.927^{* *}$ & $0.920^{* *}$ & $0.955^{* *}$ & $0.861^{* *}$ & $0.933^{* *}$ & $0.970^{* *}$ & & & & \\
\hline $\begin{array}{l}\text { Corm yield } \\
\left(t \mathrm{tha}^{-1}\right)\end{array}$ & $-0.934^{* *}$ & $0.938 * *$ & $0.966^{* *}$ & $0.932^{* *}$ & $0.964^{* *}$ & $0.972^{* *}$ & $0.969 * *$ & & & \\
\hline $\begin{array}{l}\text { Diameter of } \\
\text { corm }(\mathrm{cm})\end{array}$ & $-0.945^{* *}$ & $0.970^{* *}$ & $0.976^{* *}$ & $0.943^{* *}$ & $0.985^{* *}$ & $0.977^{* *}$ & $0.949 * *$ & $0.968 * *$ & & \\
\hline $\begin{array}{l}\text { Dry matter } \\
\text { of corm }(\%)\end{array}$ & $-0.871^{* *}$ & $0.976^{* *}$ & $0.953^{* *}$ & $0.930^{* *}$ & $0.969 * *$ & $0.911^{* *}$ & $0.890^{* *}$ & $0.930^{* *}$ & $0.970^{* *}$ & \\
\hline Starch (\%) & $-0.835^{* *}$ & $0.851^{* *}$ & $0.876^{* 8}$ & $0.774^{* *}$ & $0.853^{* *}$ & $0.841^{* *}$ & $0.914^{* *}$ & $0.887^{* *}$ & $0.847^{* *}$ & $0.829 * 8$ \\
\hline
\end{tabular}

Note: ** significant at $1 \%$ level
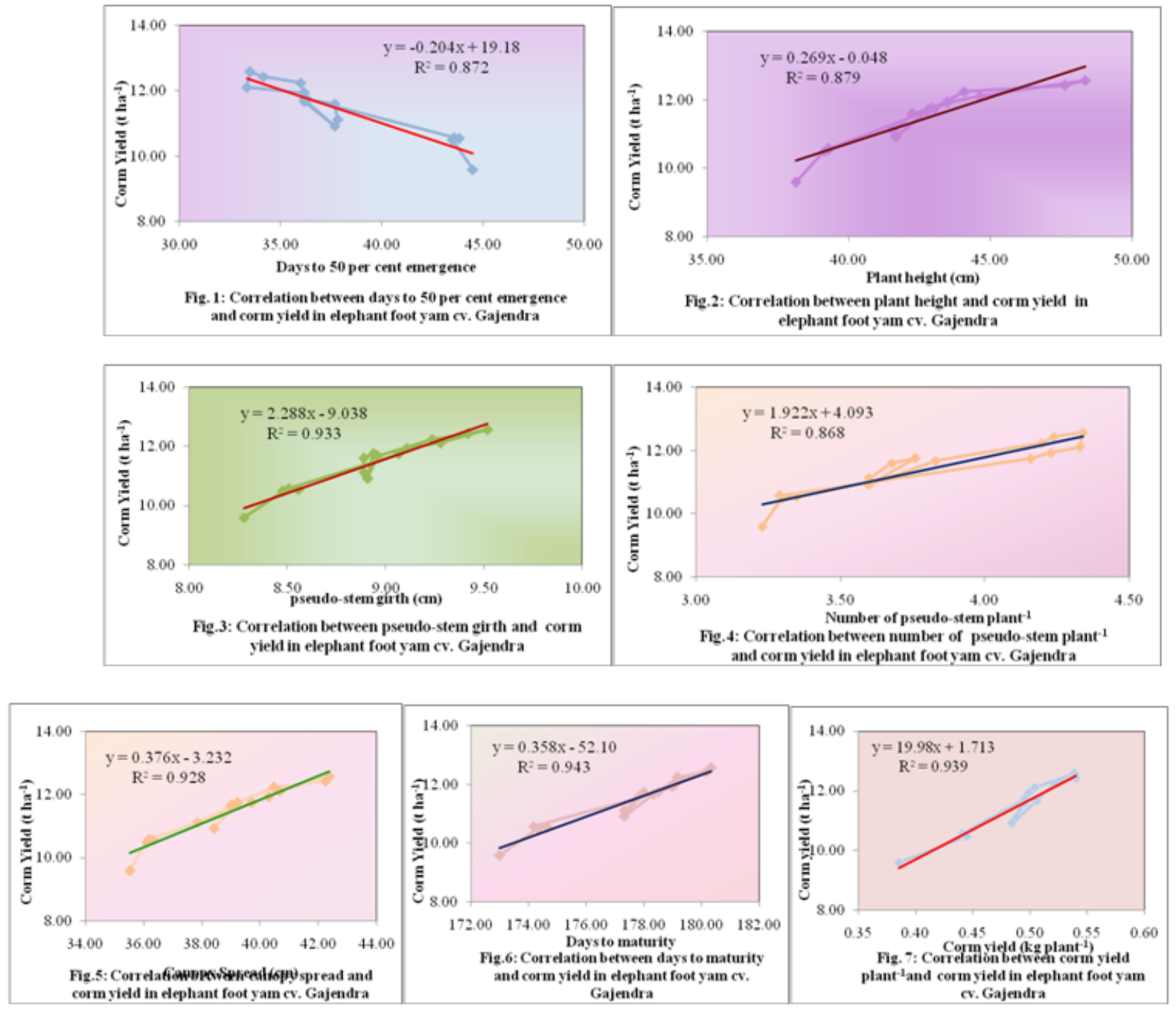
Correlation Studies of Yield and Yield Contributing Characters and Quality Parameters of...
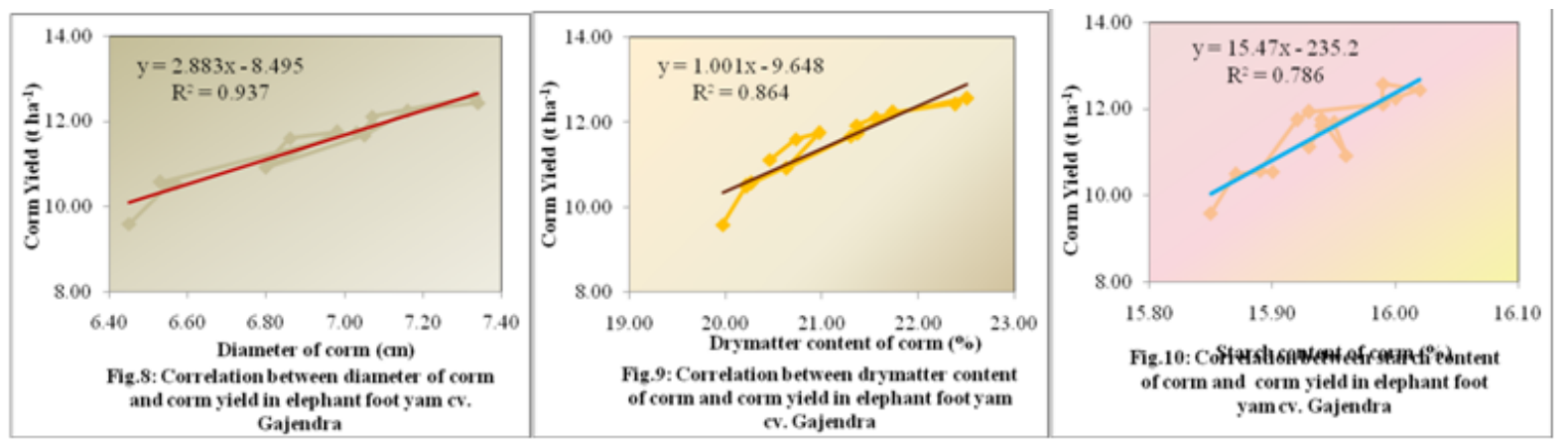